\title{
Wind risk assessment in urban environments: the case of falling trees during windstorm events in Lisbon
}

\author{
A. Lopes ${ }^{(1)}$, S. Oliveira ${ }^{(1)}$, M. Fragoso (1), J. A. Andrade ${ }^{(2)}$ and P. Pedro (3) \\ (1) Centre of Geographical Studies, University of Lisbon (e-mail: antlopes@fl.ul.pt) \\ (2) Geosciences Department, University of Évora (e-mail: zalex@uevora.pt) \\ (3) Lisbon City Council, RSBL (e-mail: pedro.pedro@cm-lisboa.pt)
}

\begin{abstract}
Trees bring many benefits to the urban environment. However, they may also cause hazards to human population, being the major causes of injuries and infrastructural damage during strong wind events. In the city of Lisbon, strong winds rather frequently result in tree falls, depending on the season and meteorological conditions. This paper presents a methodology to analyse tree damage due to strong wind events in urban environments. Each occurrence has been recorded by the Lisbon Fire Brigade and Rescue Services (Regimento de Sapadores Bombeiros de Lisboa - RSBL). Information provided by RSBL relating to the period of 1990-2005 was considered along with hourly wind speed and direction, species, fitossanitary conditions and urban parameters. To ensure that the fallen trees were caused by strong winds, only days with three or more occurrences of fallen trees were selected. It was found that in summer, northerly winds are responsible for $11 \%$ of tree falls, with winds from other directions (west, southwest and south) responsible for 5\%. From autumn to spring, perturbed weather conditions originating from the west, southwest and south are responsible for $84 \%$ of fallen trees. The majority of tree falls occurred when wind speed surpassed $7 \mathrm{~m} / \mathrm{s}$ in the six hours prior to their fall. Some recommendations to the Civil Protection Agency and the Fire Department are presented to improve the mission of collecting information. This research is a contribution to the assessment of wind risk in Lisbon.
\end{abstract}

Key words: strong winds, trees in urban streets, urban environment, Lisbon

\section{Introduction}

Planting trees brings many benefits to the urban environment (Fabião, 1996; Jim and Liu, 1997; Nilsson et al, 2000; Saebe et al, 2003; Soares and Castel-Branco, 2007). Trees have a moderating effect on the urban microclimate and improve the physical, biological and chemical aspects of the urban environment, namely by reducing the urban "heat island" effect (Alcoforado, 1992), by acting as a barrier against strong wind channelling (Lopes, 2003), by protecting urban surfaces from direct sunlight (McPherson and Muchnick, 2005), by capturing air pollutants and dust in urban areas (Freer-Smith et al, 2004) and by increasing the biodiversity, providing habitat for birds and small mammals (Clergeau, 1996). Trees also protect urban surfaces by reducing the impact of rainwater, while their roots remove nutrients that can be harmful to the water in urban soils, hence improving urban hydrology and controlling erosion. In addition, trees in urban settings sequester carbon, providing a helpful hand to combating climate change, reduce the energetic demand of the city, influence thermal and mechanic comfort and foster citizens' wellbeing (e.g., affecting physical and mental health, aesthetic and socio-economic values, common heritage, recreation benefits, etc). A 1999 World Health Organisation report revealed that in three European countries (Austria, France and Switzerland), more people died prematurely due to the effects of pollution from vehicle emissions than due to car accidents. Since a large proportion of the population is expected to continue living in urban areas, where current EU standards for PM and long-term average nitrogen dioxide are exceeded, owing mainly to roadtraffic emissions (Krzyzanowski et al., 2005), the plantation of trees in these areas must be strongly encouraged. However, excessive plantation of trees and obstructive "green masses" in ventilation paths should be avoided, because it can reduce mean wind speed and deplete dispersion conditions (Lopes, 2003; Alcoforado et al., 2005).

On the other hand, trees' benefits for the urban environment are frequently accompanied by hazards caused to the human population and infrastructure, particularly during strong wind events, due to total or partial tree falls in public and private open spaces. This is one of the major causes of human injuries (and, sometimes, death) during extreme events. For example, the extreme windstorms of 26-28 December 1999 were directly responsible for killing 95 people, injuring 11 and affecting approximately 3,400,000 people in France; killing 15 in Germany; 11 in Switzerland; 11 in the United Kingdom; and 5 in Spain. The total cost of the disaster was estimated at more than USD 10 billion

A. Lopes et al. 
(EM-DAT: the OFDA/CRED International Disaster Database). During this event, wind speed exceeded $160 \mathrm{~km} / \mathrm{h}$ in many places along the French coast and along the $49^{\circ} \mathrm{N}$ parallel. Near Paris, in Versailles, more than 4,000 trees were windthrown as a result of the storm and the French Office National des Forêts reported that an estimated 1,300,000 trees were blown away throughout the country(http://www.onf.fr/reg/Ile-de-France/versailles/ tempet.htm).

\section{The constraints of trees in the urban environment}

Windstorms damages greatly depend on the physical conditions imposed by the urban environment. In fact, the environment in urban areas is generally unfavourable for most arboreous species because climate, sun light, soil conditions and air quality are more restrictive than in the rural ones. The severity of urban conditions is not uniform, since it depends on the location of urban trees (Fabião, 1996; Nilsson et al, 2000): trees planted in paved areas (street trees) are exposed to a relatively higher level of stress than those planted in urban parks (park trees) or in small urban forests (urban woodlands). Therefore, the average life span of street trees is generally shorter than those of parks trees or trees planted in urban woodlands. Furthermore, the number of species used in urban planning in paved areas is fewer than those used in the other urban environments. For example, about $55 \%$ of all trees planted in Spanish paved areas (Garcia-Martin and GarciaValdecantos, 2001) or in Lisbon streets (Soares and CastelBranco, 2007) are represented by only five genera.

Trees planted in the urban environment, namely street trees, must be adapted to higher temperatures (heat island effect) and higher shadow levels than those observed outside urban areas. Building construction and paving are responsible for some important changes in soil conditions, such as the lowering of the phreatic water table, the removal of the soil surface layer and the soil compaction. This, thus, reduces the soil volume available for root expansion, the available nutrient content and soil permeability in addition to restricting the water and air uptake by the roots. Street trees are also damaged by the effects of air pollution, mainly by gas emissions from industries and cars, poisoned by salts, gas, oil and various piped chemical products from industries. Furthermore, they are damaged by severe and inaccurate pruning practises or by occasional events like windstorms, hail fall and physical impact caused by cars and building materials. Finally, street trees can also be damaged by inadequate procedures during planting, particularly those concerning the planting depth, the dimension of the planting holes and transplant shocks caused by changes in urban dynamics regarding their proximity to new paving or the opening of ditches and by insects and diseases (Fabião, 1996; Saebe et al., 2003).

Thus, the survival and failure of urban trees are a consequence of the simultaneous action of all of the abovementioned abiotic and biotic factors. As such, the ability of trees to resist these environmental factors must be taken into account both by selecting wind-resistant species and evaluating the damage to trees caused by windstorms. A simple relationship between the observed damage and the measured wind speed is not enough to evaluate wind damage to trees.

\section{Wind damage to urban trees}

The effects of windstorms on urban trees also depend on the inherent characteristics of each of the species (e.g., age, size, height, bearing, density of the foliage, width of the fustic, density of the wood, etc.), as well as its cultural and health conditions. After two hurricane events in Florida in the United States (Hurricane Erin, 2 August 1995, with $37 \mathrm{~m} / \mathrm{s}$ sustained wind and peak gusts of $45 \mathrm{~m} / \mathrm{s}$, and Hurricane Opal, 4 October 1995 with 56-65 $\mathrm{m} / \mathrm{s}$, respectively), Duryea (1997) noted that "species that grow into large trees were more likely to cause property damage than small trees". Sand pine (Pinus clausa), slash pine (Pinus elliottii), longleaf pine (Pinus palustris) and laurel oaks (Quercus laurifolia) were more likely to cause damage if they fell than the smaller Southern red cedar (Juniperus silicicola), Carolina laurelcherry (Prunus caroliniana) and Chinese tallow (Sapium sebiferum). Besides the size there is a predisposition to Florida native trees, like the dogwood (Cornus florida), sand live oak (Quercus geminate), live oak (Quercus virginiana), sabal palm (Sabal palmetto), and Southern magnolia (Magnolia grandiflora), to tolerate hurricane-force winds extremely well. Some foreign species have the predisposition to be affected by insects and disease after experiencing strong winds and are less resistant (Duryea, 1997).

Trees in natural environments are optimised structures which are subjected to static and dynamic loads (Mattheck and Breloer, 1994). According to James (2003), the strength of each structural member depends on the size of the crosssection (the base of the trunk being the strongest part where static loads are the greatest), the shape of the crosssection (a circular section being best adapted to torsional forces) and the strength of the material (young wood being more flexible than old wood). Trees also show some physical features of adaptive growth against wind loads. For example, the growth rings are thicker on the side where the dynamic (wind) load is greatest and thinner on the opposite side, while the base of a trunk or branch is massive due to the addition of wood and, thus, represents a localised reinforcement to withstand the high (static) loads. In the urban environment, trees experience a wind dynamic load that produces a complex sway motion in trees: more lateral movements are caused by wind than in forests, where trees are protected by their neighbours. Furthermore, the energy is transferred from the wind to the main structure of the trunk (damping effect) and consequently, dissipated by the leaf drag, wood and root/soil system, and partly by branch sway (James, 2003). 


\section{Urban climate and environment of Lisbon}

Lisbon is the capital and largest city of Portugal and is located at $38^{\circ} 43^{\prime} \mathrm{N}$ and $9^{\circ} 09^{\prime} \mathrm{W}$, some $30 \mathrm{~km}$ to the east of the Atlantic shore, on the bank of the Tagus estuary. The climate is Mediterranean (Csa according to Köppen's classification), characterised by mild winters (61-90 climatological normal temperature, in January, from minimum $8.2^{\circ} \mathrm{C}$ to maximum $14.5^{\circ} \mathrm{C}$ ) and dry, hot summers (in August, from $17.7^{\circ} \mathrm{C}$ to $27.9^{\circ} \mathrm{C}$ ). The annual precipitation is $751 \mathrm{~mm}$.

The summer wind regime in the city of Lisbon is dominated by a relatively strong northerly wind that occurs near the western coast of the Iberian Peninsula, the Nortada (Fig. 1)

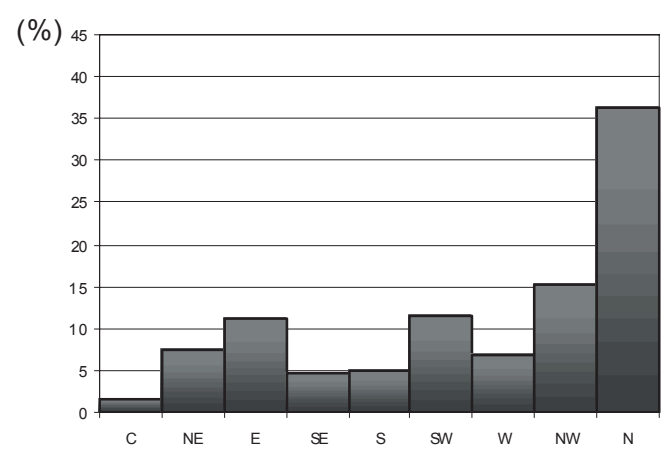

Fig. 1 - Wind direction in summer (June to August) at Lisbon airport (1971-2000) at 12:00 p.m.

Source: Alcoforado and Lopes (2003)

This regional circulation occurs when a strong pressure gradient is maintained by a persistent thermal depression in the warm continent and the Azores anticyclone is above the cooled ocean. The upwelling of the cooler ocean waters near the shore reinforces the pressure gradient, increasing wind speeds near the ground. In Lisbon, the Nortada is very important in what concerns air quality and comfort, since it promotes the dispersion of pollutants and, at the same time, reduces both the natural and anthropogenic heat loads. Alcoforado (1987) found that N and NW are the most frequent wind directions for $45 \%$ of summer days. From June to September (27\%) the Nortada was considered strong (hourly mean wind speed $\geq 15 \mathrm{~km} / \mathrm{h}$ ), though wind velocities can reach $50 \mathrm{~km} / \mathrm{h}$ in the early afternoon, and maximum gusts of $70 \mathrm{~km} / \mathrm{h}(19.4 \mathrm{~m} / \mathrm{s})$ in the late afternoon.
Consequently, the mechanical effect of strong winds on people can be unpleasant, especially in the leisure areas: with a wind-effective speed greater than $9 \mathrm{~m} / \mathrm{s}$, the performance of a pedestrian in a street is significantly affected, while an effective wind greater than $20 \mathrm{~m} / \mathrm{s}$ is hazardous for weaker persons (Saraiva et al, 1997). Experiments conducted in a wind tunnel with a physical model of the eastern part of Lisbon showed many critical points (from the security point of view) in the streets. Findings show that more than 43 hours per year could be critical, with effective wind velocities greater than $20 \mathrm{~m} / \mathrm{s}$. Sudden gusts in these areas could be dangerous for weak or unprepared persons and trees should be planted to prevent damages (Saraiva et al, 1997).

In winter, winds blow mostly from $\mathrm{SW}, \mathrm{W}, \mathrm{NW}$ and $\mathrm{N}$. However, from March onwards, there is a great increase in the frequency of northerly winds (Alcoforado, 1992). Northeast is the most frequent wind direction in December (30\%), but the north direction is still a strong component (13\%). In January and February, the west direction is persistent and at the end of the winter season the north direction becomes more important (Fig. 2). Although the wind blowing from south and southwest directions are not the most frequents directions, they can cause serious damages to urban trees (Lopes, 2003).

In Lisbon, the windy weather conditions occur more frequently during the winter, when the westerly flow is more intense, bringing more tracks of frontal disturbances to the Portuguese latitudes. These winter cyclonic circulations are related to three main large-scale patterns, two of them with a clear connection to low-pressure systems located just to the west of the British Isles: i) westerly or north-westerly winds could blow over Portugal in connection with travelling frontal systems that extend as far as southern Portugal; ii) in other cases, windy weather conditions are related with "westerly and south-westerly winds from the North Atlantic that occur over Portugal along the southern flank of cyclone systems, which have a high moisture content, particularly over northern and central Portugal" (Santos et al., 2005, p. 38); iii) a third type of large-scale circulation is related with southerly winds associated with cyclonic circulations which are, in turn, connected with the more southerly path of the westerlies in the mid-tropospheric flow. These cyclonic circulations at the lower levels are mainly controlled by low pressure centres located to the west or southwest of Portugal.

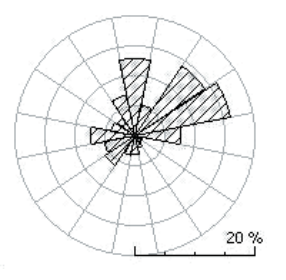

December

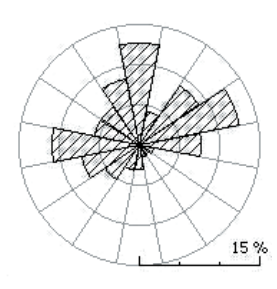

January

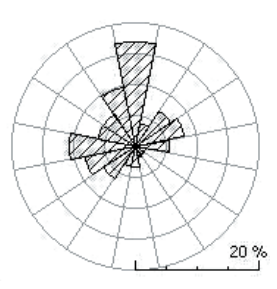

February

Fig. 2 - Winter windroses at the Lisbon/Airport (1971-1980).

Source: Lopes (2003)

\footnotetext{
A. Lopes et al.
} 
In the last 30 years, some windstorms causing damage to trees have been reported in Lisbon, with maximum gusts of $22 \mathrm{~m} / \mathrm{s}$ to $33 \mathrm{~m} / \mathrm{s}$ ( 80 to $120 \mathrm{~km} / \mathrm{h}$ ). This corresponds to a statistical return period from 2 to $7-8$ years (Borges, 1971). The OFDA/CRED International Disaster Database indicates the occurrence of a small number of deaths and injuries during windstorms in Portugal, most of them caused by fallen trees.

\section{Green areas and trees in Lisbon}

Since the 15th century, the city of Lisbon was the point of departure for the discovery of new lands. During many centuries, Portuguese ships traveled around the world in search of new trade routes and, since then, exotic tree species were introduced in Europe and many gardens of foreign species were built in the city. In the 19th century, parks and public gardens were integrated in new urban strategies. These green spaces today contain a wide variety of species, some being Mediterranean (or well adapted to the Lisbon climate) but also many exotics, from Southeast Asia, Central America, Australia, the Pacific Islands and even from cold climates (Moreira, 1998).

At present, the Green Index of Lisbon (which corresponds to the mean value of green areas, mainly covered by trees) has an average value of $26.8 \mathrm{~m}^{2} /$ inhabitant (including Parque de Monsanto, the largest continuous geen area in the urban perimeter of Lisbon (Soares and Castel-Branco, 2007). Excluding the Parque de Monsanto, this value decreases to $9.1 \mathrm{~m}^{2}$ /inhabitant (Fig. 3).

Since the early $20^{\text {th }}$ century, several inventories and studies of the trees in the city of Lisbon were made. The first list dates back to 1929 and the last one available is from 2003 (Fig. 4). The most representative species found in Lisbon's streets are the European nettle tree (Celtis australis L.), the plane tree (Platanus hybrida Brot.), different species

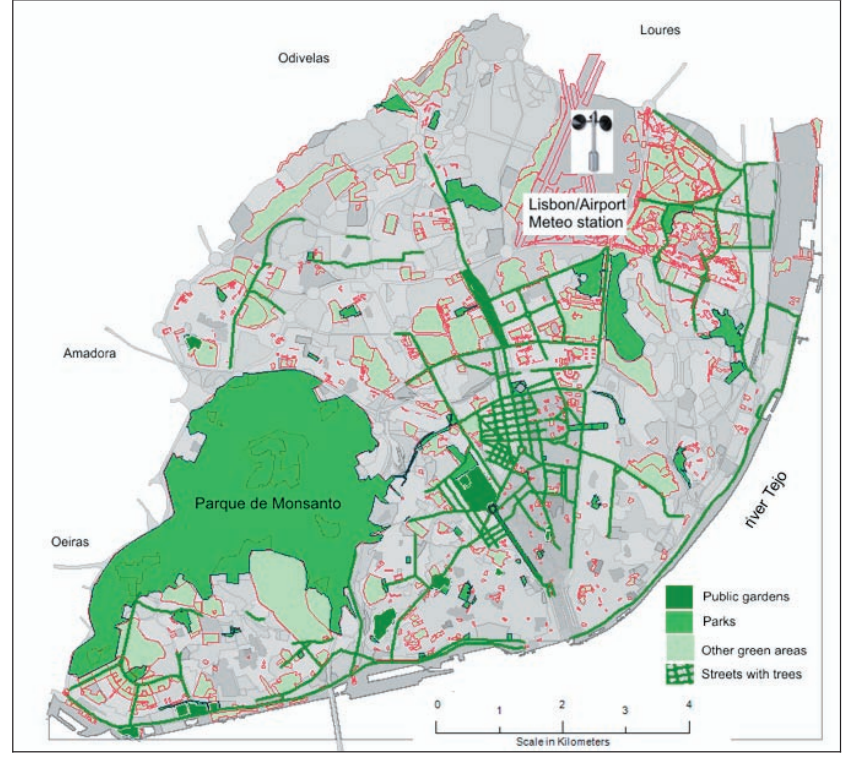

Fig. 3 - Lisbon's green structure.

Source: Lisbon City Council

of limes (Tilia spp.), blue jacaranda (Jacaranda mimosifolia D.Don.), box elder maple (Acer negundo, L) and different species of poplars (Populus alba L., Populus nigra L. and Populus $x$ canescens) (Soares and Castel-Branco, 2007). It was verified that the proportion of species varied along this period: for example, while Celtis australis exists in the city since 1929 in a large proportion, Acer negundo was only found in 2003.

Today, more than 70 monumental trees (or groups op trees) are a part of our heritage worth preserving: it includes a variety of species, some exotic (e.g., Phoenix dactylifera L, Ficus macrophylla Desf. Ex Pers., Tipuana tipu (Benth.) Kuntze, Brachychiton spp., Cupressus macrocarpa Hartweg ex Gordon, etc.) and others representative of our

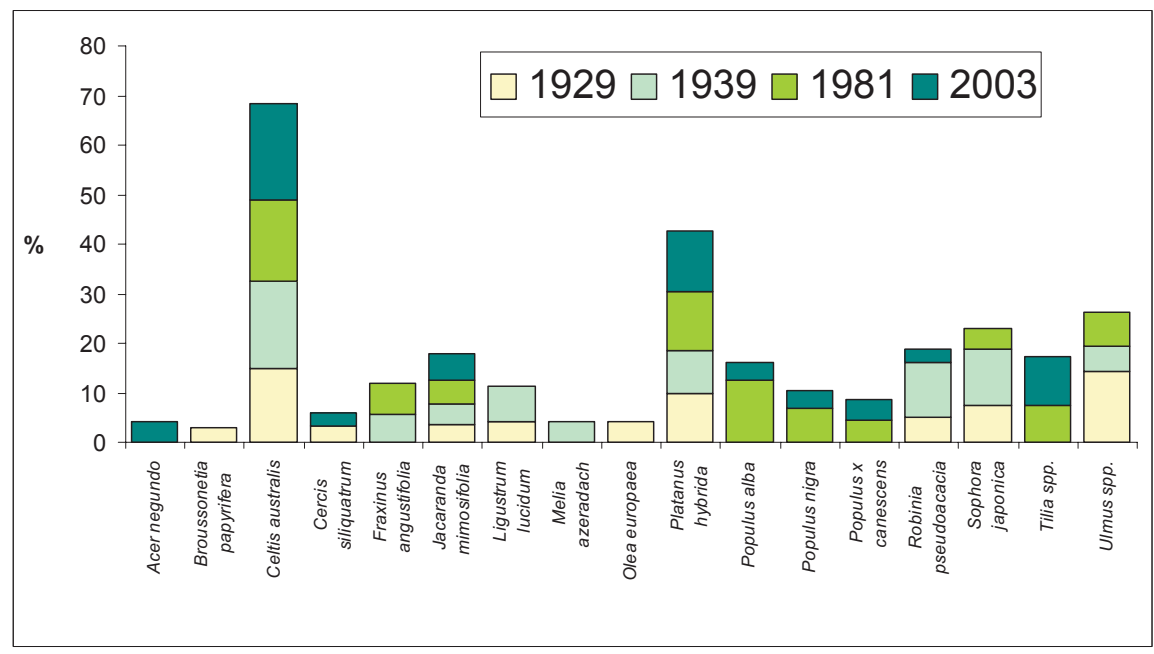

Fig. 4 - The dominant tree species found in the streets of Lisbon in each inventory.

Source: Soares and Castel-Branco, 2007. 
local flora (e.g, Q.suber, Q. rotundifolia, Q. robur, Q. faginea, Q.coccifera, P. pinea. Arbutus unedo, Phillyrea latifolia, Pistacia lentiscus, Viburnum tinus, Rhamnus alaternus, Juniperus turbinate, Olea europaea, etc.), most of them in parks and public gardens (11 centenary specimens) (DGRF, n.d.). Many species are adapted to the Mediterranean climate, although the urban heat island can stimulate biological activity by advancing phenological phases, for example.

\section{Data and Methods}

For this study, a series of 16 years was used, from 1990 until 2005 , corresponding to the latest available data of fallen trees. This data was obtained from the information compiled by the Lisbon Fire Brigade and Rescue Services (Regimento de Sapadores Bombeiros de Lisboa - RSBL), which handles emergency calls and is also in charge of cleaning up the areas and notifying the Lisbon City Council. The time of the fallen tree occurrences is registered in the RSBL database as the time of the call to the call centre. Information about the place where it occurs includes: the description of the street name and the nearest door number, crossroad, light pole number or a building easy to identify (e.g., school, church, bank, etc). In few cases, it is possible to acquire specific details about the species, the dimension of the tree, the probable cause of the occurrence and the damages caused by the event.

However, it is important to point out that the information collected by the RSBL has certain limitations:

The time registered by the fire brigade corresponds to the time of the emergency call and not to the tree fall; there may be a significant time difference between the occurrence and the call, which remains unknown;

The occurrences recorded refer only to the incidents that have caused disturbances or damages to people, which excludes the falls that occur where no one is affected;

Information on the species, dimension, age and health conditions of the trees, which is essential to understand the relations between the meteorological conditions and the fall of trees, is seldom included;

The methodology applied by the RSBL to register the occurrences changed during the study period. The record books changed in 1994 and 1997 and, consequently, so did the type of information included. In addition, the method of registry and the terminology used among the RSBL technicians are not well defined.

Until 1998, the occurrences were recorded in a book and, after that, on a digital format. The data recorded in paper had to be collected from the archives of the RSBL and entered into a digital database created specifically for this work. Considering that this was a time-consuming task and that the main purpose of this study was to assess the adequacy of the proposed methodology, it was not possible to make a visual check of all available data.
A selection of the days between 1990 and 1998 with a higher probability of occurrences was carried out, based on the analysis of meteorological data (only when strong wind events occurred). The threshold for assuming these events was based upon basic statistics and is explained later in this section.

The meteorological data used were hourly wind speed and direction at the Lisbon Airport meteorological station. Due to the impossibility of verifying how much time had elapsed between the incident and the emergency call, each occurrence in the database was matched with the wind data (speed and direction) recorded at the start of the hour. In addition, each occurrence also corresponded to the mean and maximum wind speed values recorded in three, six, nine and 12 hours prior to the call put in to the Fire Brigade. To ensure that only occurrences caused by meteorological conditions were included, only days with three or more incidents were selected. At a first stage, this analysis was applied to the set of data available initially for the period of 1999-2003. It was found that the majority of tree falls happened when certain wind speed limits were surpassed, specifically above $7 \mathrm{~m} / \mathrm{s}$ for the time period that included the six hours prior to the call. The same methodology was then applied to the data for the period of 1990-1998 and the days with higher probability to the occurrence of tree falls due to meteorological conditions were selected, based on the threshold found. The collection of data from the archives of RSBL was carried out afterwards. It was verified that the methodology applied to select the days was rather precise and efficient; even so, the two days before and after each occurrence were also visually checked.

Finally, all the information obtained was introduced into a GIS in order to detect the relationships between the tree falls and the characteristics of the places where they occur, such as the H/W ratio, aerodynamic roughness, distance to high-density areas, relation between the wind direction and street orientation, etc. Some technical problems were encountered, namely the precise location of the trees. In such cases, the central coordinate of the street, or the nearest feature found was attributed as the location of the occurrence. The problems encountered will be addressed with the Fire Brigade in order to facilitate the future collection of data. Some suggestions are put forth in this paper's "Conclusions and further research" section.

The authors collected newspapers and online news articles regarding the occurrence of extreme climatic events for the last several years. Such data has proven to be an important source of information, with a necessary filter attitude. Some examples are presented later on in this paper.

Although the authors produced monthly products, here a general view by "season" has been adopted in order to simplify the results. The months are not aggregated by means of astronomical or thermal criteria. Instead, we used the methodology of Lopes (2003), to obtain the general wind regime at the Lisbon/Airport meteorological station. The author used a series of 10 minute wind speed

A. Lopes et al. 
and direction data, from the period of 1971-1980. A tree diagram and a principal component analysis of both $A$ and $K$ of the Weibull function revealed that September has a clearly different wind regime from other summer months (June, July and August), and was included in the autumn months (September to November). Winter comprises the period from December to February. March, April and May were considered to be the months of spring.

\section{Preliminary results}

\section{Tree falls in Lisbon from 1990 to 2005: a general overview}

Between 1990 and 2005, 946 occurrences of trees, boughs and branches falls were observed during strong wind events. As can be seen in Figure 5, there was a large variation in the number of occurrences by year: the highest percentage of incidents occurred in the years of 1997, 2000 and 2001. About $61 \%$ of the incidents occurred in the 20002005 period, with a maximum of $18.7 \%$ in 2000 . In June of this same year, strong winds (wind gusts of $85 \mathrm{~km} / \mathrm{h}$ $\approx 24 \mathrm{~m} / \mathrm{s}$ ) were reported only in the Lisbon region (where a person who was waiting for the bus was badly injured); in the beginning of November, a wind storm swept throughout the country (with floods and high-intensity precipitation that surpassed $90 \mathrm{~mm}$ in a period of 24 hours in some places in northern Portugal). On 6-7 December, a very active cold front passed over the country and the Lisbon Region was very affected (gusty winds of $100 \mathrm{~km} /$ h). The civil protection service alerted to the population about the event, and confusion set in the city, with thousands of people working in the city that live in the suburbs trying to escape the storm. This occurrence led the city into chaos (as noted by Portuguese newspapers), which is a good example of how civil authorities should deal with the divulgation of information. "The repeated warnings about bad weather, the deterioration of the situation throughout the day and the expectation that it might worsen at nightfall all left the population in a state of comprehensible anxiety" (Jornal de Notícias online edition, 7 December 2000). In the end, the city sustained only light damages, though it led to great fright due to rumours.

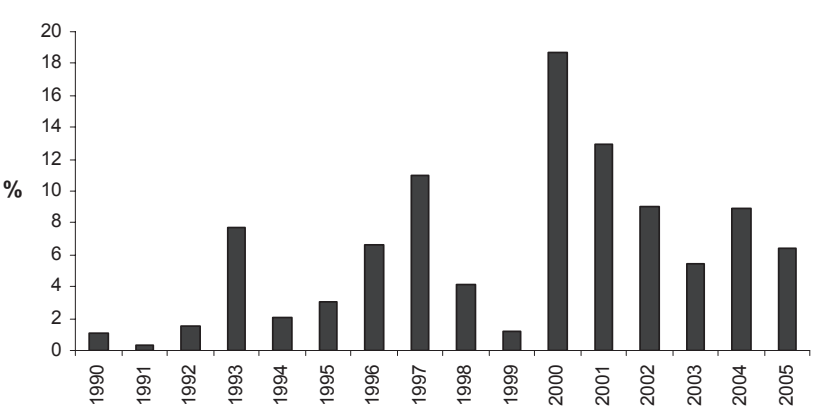

Fig. 5 - Percentage of occurrences of tree, bough and branch falls registered in the database for the period of 1990-2005.

When the 16-year period was analysed according to each direction, it was found that over $55 \%$ of the tree falls occurred with south and southwest winds $(27.9 \%$ and $27.5 \%$, respectively), $13.2 \%$ were caused by west wind and $12.3 \%$ from winds from the northwest. Only 1.3\% of the occurrences were caused by east winds (Fig. 6a).

When the data was analysed by season, it was found that more than $60 \%$ of tree and branch falls in the city occur during the autumn and winter. In the summer, the $\mathrm{N}$ and NW winds are dominant, while in the other seasons, winds from the S and SW cause the majority of falls (Fig. 6b). The first situation is due to the prevailing Nortada, as explained above. In the "coldest" time of the year the "extreme" synoptic situations are due to a relatively high frequency of South depressions and storms associated to the cold front.

The wind speed also varied according to the direction. At the time of the occurrences, winds recorded from South and North reached higher speeds, over $7 \mathrm{~m} / \mathrm{s}$. The averages of the maximum speeds recorded for the $3 \mathrm{~h}, 6 \mathrm{~h}$ and $12 \mathrm{~h}$ prior to the falls were calculated and compared (Fig. 7). It was found that the maximum speed increases with time passed from emergency call, meaning that the maximum wind speed for the period of $12 \mathrm{~h}$ prior to the occurrence is higher than the maximum speed for the previous $3 \mathrm{~h}$ and $6 \mathrm{~h}$ periods (Fig. 8). These results can be due to the time
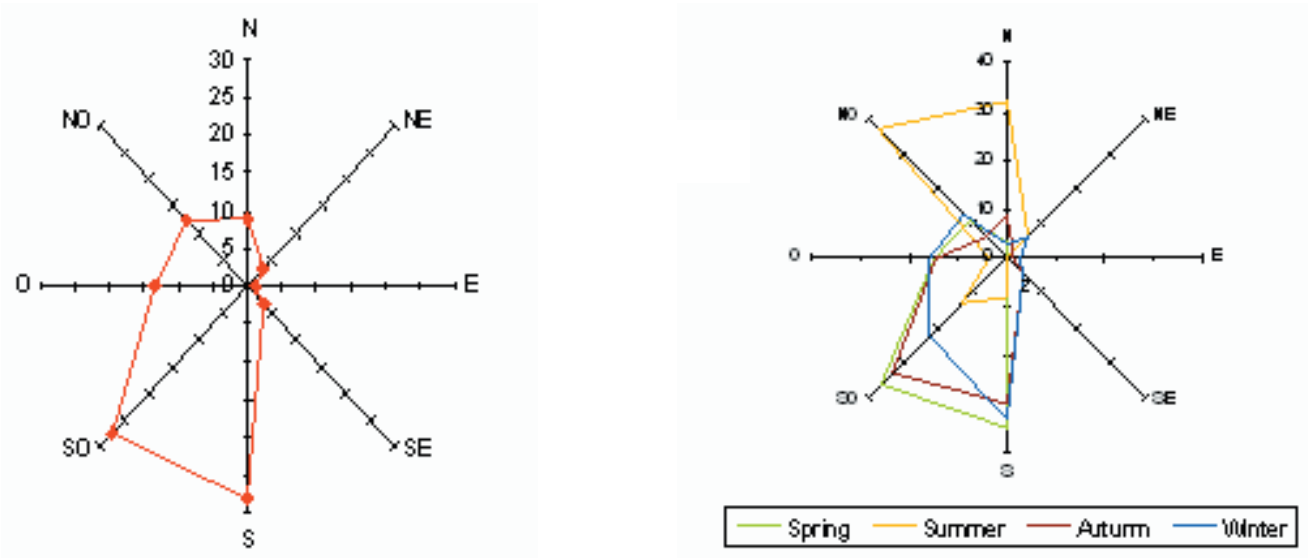

Fig. 6 - Occurrences according to the wind direction (left) and season (right).

\footnotetext{
A. Lopes et al.
} 
lag existing between the moment of the occurrence and the moment it is recorded in the database. Also, many situations may occur during the night and only in the morning, after people wake up, the call is made. The west direction is a curious situation, as the value from the 6 to 12 hours prior to the occurrence is greater than all other directions.

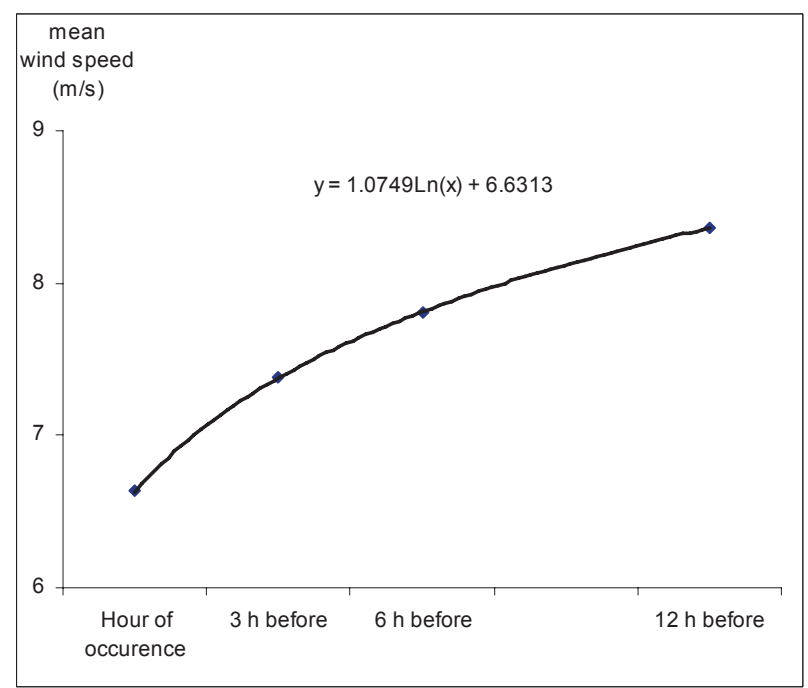

Fig. 7 - Mean wind speed at the hour of the falls and in the previous hours

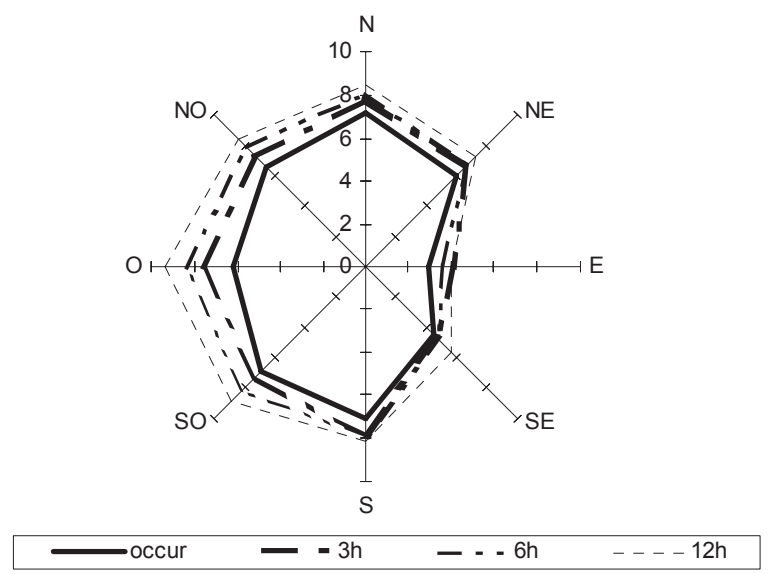

Fig. 8 - Maximum wind speed at the hour of the falls and in the previous hours.

\section{The example of the windstorms of 8 October 2004}

On 8 October 2004, the Iberian Peninsula was under the influence of a low pressure centre located in the Atlantic Ocean. Consequently, the flux was from south and southwest over Portugal.

A high number of trees, boughs and branches (35 occurrences, recordedbetween 9.30 amand $6.40 \mathrm{pm}$ ) hadfallen in the city. The wind speed began to increase significantly from 9.00 a.m., reaching a maximum of $15 \mathrm{~m} / \mathrm{s}$ at 2.00 p.m., with its speed considerablydecreasing from that time onwards (Fig. 9).

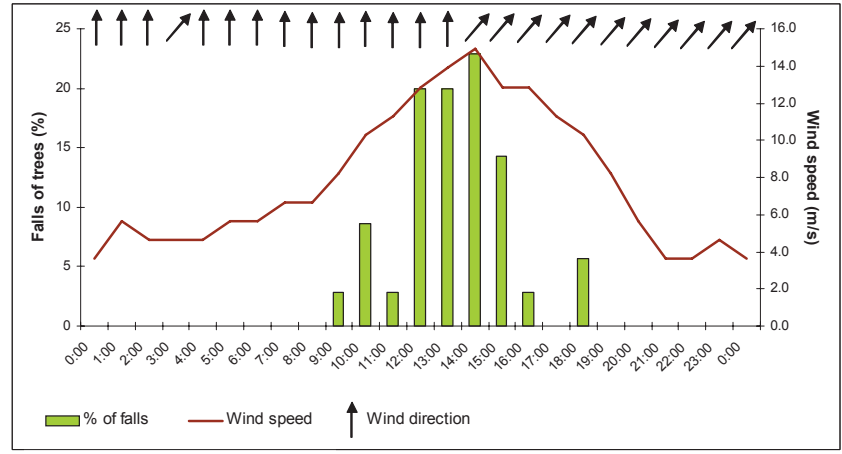

Fig. 9 - Relation between tree falls and wind (speed and direction) on 8 October 2004

As the wind speed increased, its negative impact on the city became clearer, and the tree falls were directly related to it. Between 12.00 p.m. and 4.00 p.m., the wind speed varied between $13 \mathrm{~m} / \mathrm{s}$ and $15 \mathrm{~m} / \mathrm{s}$ and $80 \%$ of the trees fell, (28 of the total of 35). This peak in occurrences coincided with the period of maximum gust $(27 \mathrm{~m} / \mathrm{s})$.

Most of the occurrences took place in the south and southwest parts of the city, in relation to the abovementioned synoptic situation. In the morning (prior to 1.00 p.m.), tree falls were caused by flows from the south; in the afternoon, a wind shift towards the southwest led to the remaining occurrences (Fig. 10).

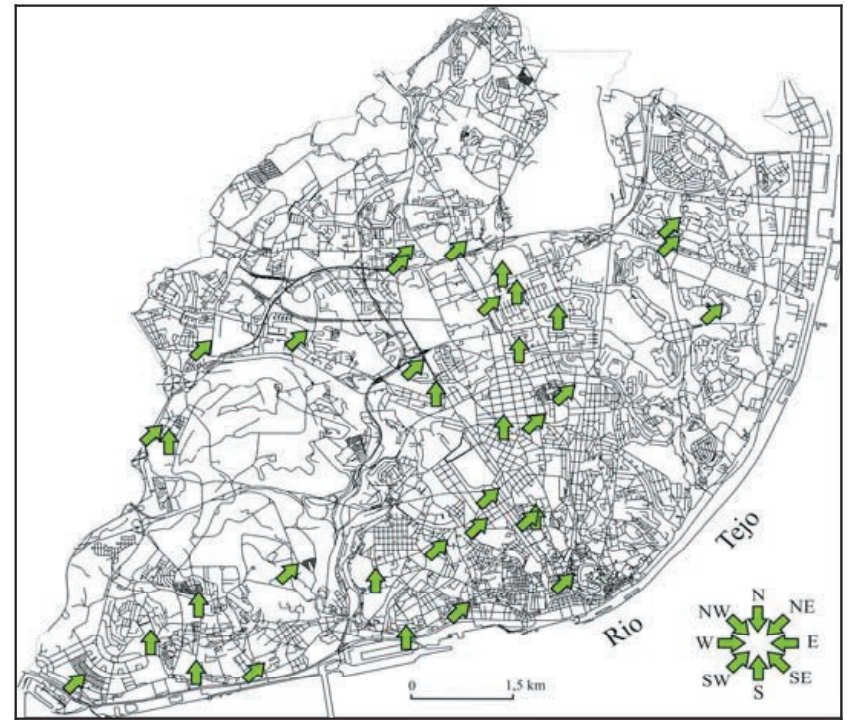

Fig. 10 - Pattern of fallen trees according to wind direction during the windstorm of 8 October 2004.

The distribution of occurrences was analysed in relation to the different land uses and ventilation classes defined for the city of Lisbon (Alcoforado et al, 2005). It was found that $41 \%$ of the fallen trees took place in densely builtup areas (where at least $50 \%$ of the area is covered with high-density buildings) in the southern part of the city, and $20 \%$ in green areas. Although these districts have greater roughness length $\left(\mathrm{z}_{0} \approx 1 \mathrm{~m}\right)$ and therefore diminish regional wind speed by about $30 \%$ comparing with non-occupied 
Table I - The characteristics of the identified trees for the episode of 8 October 2004.

\begin{tabular}{lccc}
\hline \multicolumn{1}{c}{ Species } & \% of trees & Tree Foliage & Average height \\
\hline Populous nigra (black poplar) & 25 & deciduous & 17 \\
Sophora Japonica (Japanese pagode tree) & 21 & deciduous & 12 \\
Acer negundo (box elder) & 18 & deciduous & 15 \\
Jacaranda mimosifolia (jacaranda) & 12 & semideciduous & 11 \\
Tilia tomentosa (lime) & 8 & deciduous & 19 \\
Ulmus minor (elm tree) & 4 & deciduous & 20 \\
Cercis siliquastrum (Judas tree) & 4 & deciduous & 7 \\
Ficus carica (fig tree) & 4 & deciduous & 4 \\
\hline
\end{tabular}

areas (Lopes, 2003), local acceleration through the narrow streets can occur during extreme wind events. Therefore, an index capable of translating the narrowing of the streets should be included in the analysis. This index could be given by the relation between the height of the buildings and the width of the streets (height/width) and should be applied in future research.

In relation to the species affected by these events, it was possible to identify 24 fallen trees, which were distributed among eight species (Table I). It was found that $48 \%$ of the trees only suffered damages to their upper parts (e.g., branches and boughs) and over half (52\%) were uprooted. Of all the cited species, the black poplar was the most affected by this strong event, corresponding to one-quarter of all tree falls. In this case, the cause of the falls is not very well understood and other constraints, especially the fitossanitary conditions, may have a great influence on the resistance of trees. In future research, all the conditions should be included in the database and should be analysed in depth.

\section{Atmospheric analysis of two windstorm events in Lisbon: $18^{\text {th }}$ July and $24^{\text {th }}$ November 2006.}

This section presents a diagnosis of the atmospheric environment associated with two severe windstorms triggered in quite different synoptic situations and thermodynamic conditions.

The first windstorm (18 July 2006) was a local storm, with strong gusts probably induced by convective motions and instability in the troposphere above the Lisbon area. The second windstorm (24 November 2006) was related with a clear synoptic forcing and high pressure gradients affecting the surface atmospheric circulation over the Portuguese area.

The 18 July windstorm occurred under moderately warm weather conditions. In the previous days, the synoptic situation was influenced by the Azores subtropical high. After 17 July, the surface circulation (Fig. 11a) over the western part of the Iberian Peninsula became conditioned

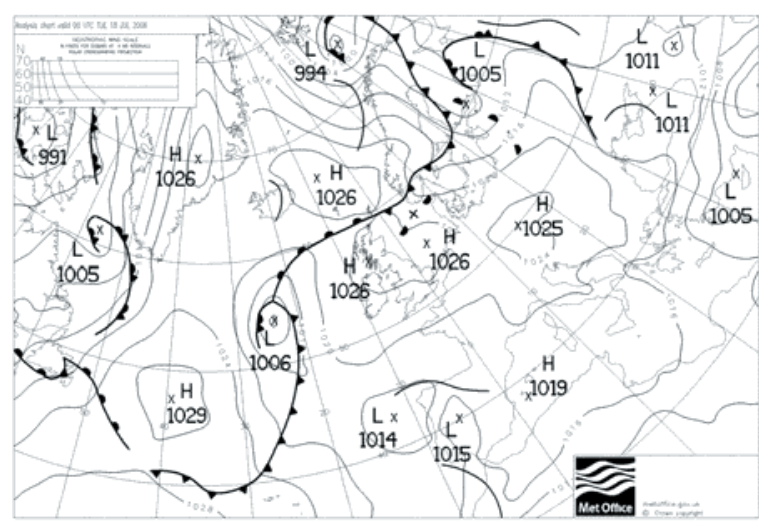

a)

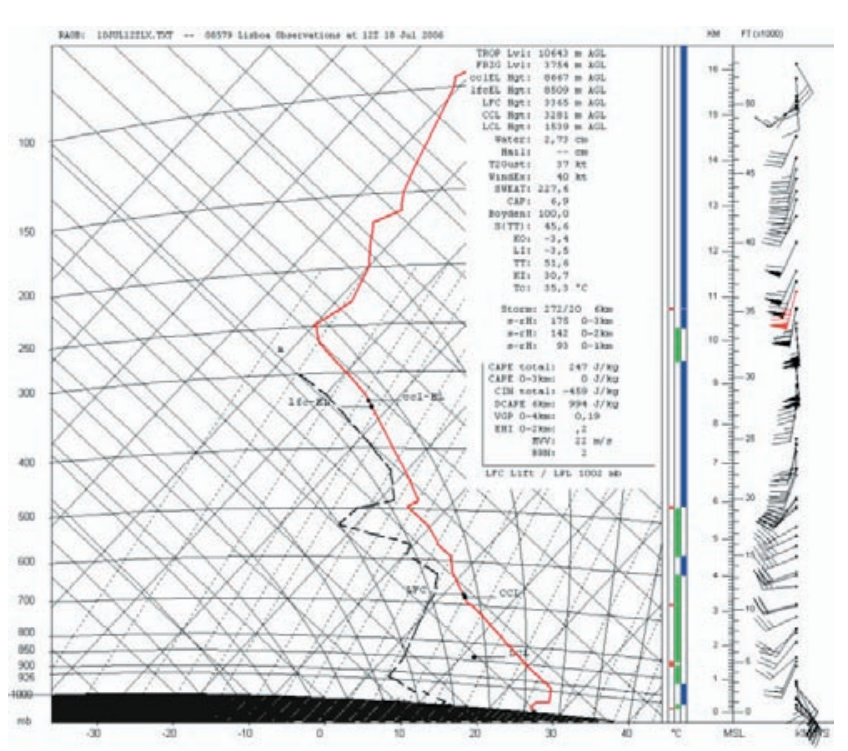

b)

Figure 11 - Windstorm on 18 July 2006: a) Synoptic chart; b) sounding over Lisbon Airport (1200 UTC). Source: MetOffice (U.K.) and University of Wyoming, Dep. of Atmospheric Science. 
by shallow (thermal) low pressure, with southerly (SW to $\mathrm{SE}$ ) winds into the Lisbon area in the low levels of the troposphere. Nocturnal temperatures remained above $20^{\circ} \mathrm{C}$ and the maximum temperature reached $32^{\circ} \mathrm{C}$ at the Lisbon Airport meteorological station. In this atmospheric environment, local thunderstorms were formed in the southwestern part of Portugal on 18 July 2007 , and the associated convection was responsible for a windstorm affecting Lisbon by the end of the morning, with the most intense wind records observed at the Lisbon Airport meteorological station. The hourly wind speed at this location increased irregularly during that morning. The maximum hourly wind speed was recorded from SE, with a mean speed of $10.8 \mathrm{~m} / \mathrm{s}$ (with a maximum gust of $18 \mathrm{~m} / \mathrm{s}$ ) and occurred at 11.00 a.m.

The analysis of the 1200 UTC Lisbon sounding (Fig. 11b) allowed the authors to understand the dynamic causes of this windstorm, taking into account that the maximum gusts occurred around that moment. Combining different sounding-derived parameters, some features of the thermodynamic factors of the windstorm could be found. Table II shows several indices and parameters of instability.

Table II - Sounding derived parameters

\begin{tabular}{cc}
\hline Indices (Units) & Lisbon/Airport 1200 UTC \\
\hline CAPE (J/kg) & 247 \\
DCAPE (J/kg) & 994 \\
WINDEX (knots) & 40 \\
T $^{2}$ Gust (knots) & 37 \\
SWEAT (nondimensional) & 227.6 \\
\hline
\end{tabular}

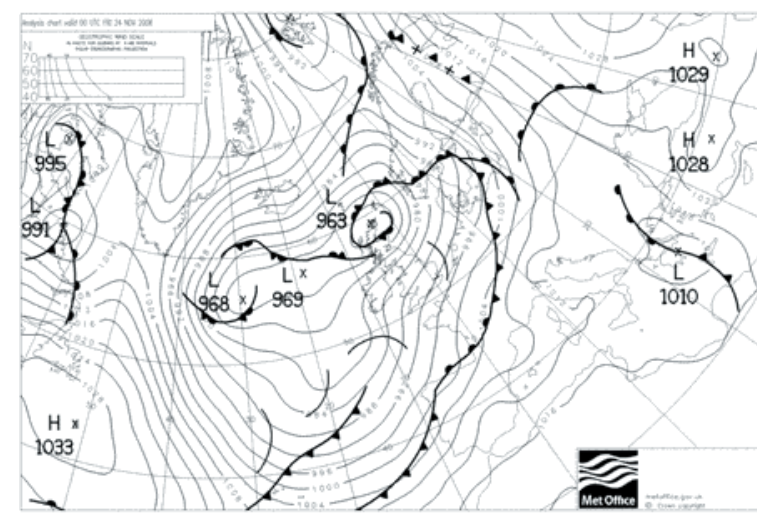

a)
The thermodynamic structure represented in the sounding (Fig. 11b), exhibit different important features favourable to the activation of strong downdrafts, probably triggering gusts in the lower troposphere. The thunderstorm activity has started earlier, but the CAPE value $(247 \mathrm{~J} / \mathrm{kg})$ suggests its possible continuation to the afternoon period. A jet stream at the upper levels was also present, underlying a troposphere marked by strong wind shear. But it is most interesting to verify the effects of a thick dry air layer below $700 \mathrm{hPa}$, inducing strong negative buoyancy, with the DCAPE value reaching $994 \mathrm{~J} / \mathrm{kg}$ (Table II). This highly instable environment has resulted in downdrafts that, very probably, were at the origin of the strong gusts experienced at the surface in the Lisbon area. This event was responsible for 11 fallen trees, boughs and branches.

The second windstorm studied occurred on 24 November 2006 and its dynamic causes were quite different from those of the previous event. The synoptic circulation over the Iberian Peninsula (Fig. 12a) was controlled by the influence of an intense frontal cyclone (low minimum of $969 \mathrm{hPa}$ at $0000 \mathrm{UTC}$ ), its centre being located west of the British Isles. On 24 November, Portugal was affect by strong surface pressure gradients, ensuring the occurrence of persistent windy weather conditions. The daily mean hourly wind speed observations at the Lisbon Airport meteorological station was $9.5 \mathrm{~m} / \mathrm{s}$, from southwest or south in almost all the time records. By $9.00 \mathrm{pm}$, the wind gust was at $23 \mathrm{~m} / \mathrm{s}$.

By the end of the morning, the Lisbon area was crossed by a cold front moving from west to east, and the most intense winds occurred just after this passage. Wind speed observations between 11 and $13.5 \mathrm{~m} / \mathrm{s}$ were registered from 12.00 p.m. to 2.00 p.m. The sounding (Fig. 12b), reveals strong southwesterly fluxes from the upper troposphere (where a jet stream is visible) until the surface levels.

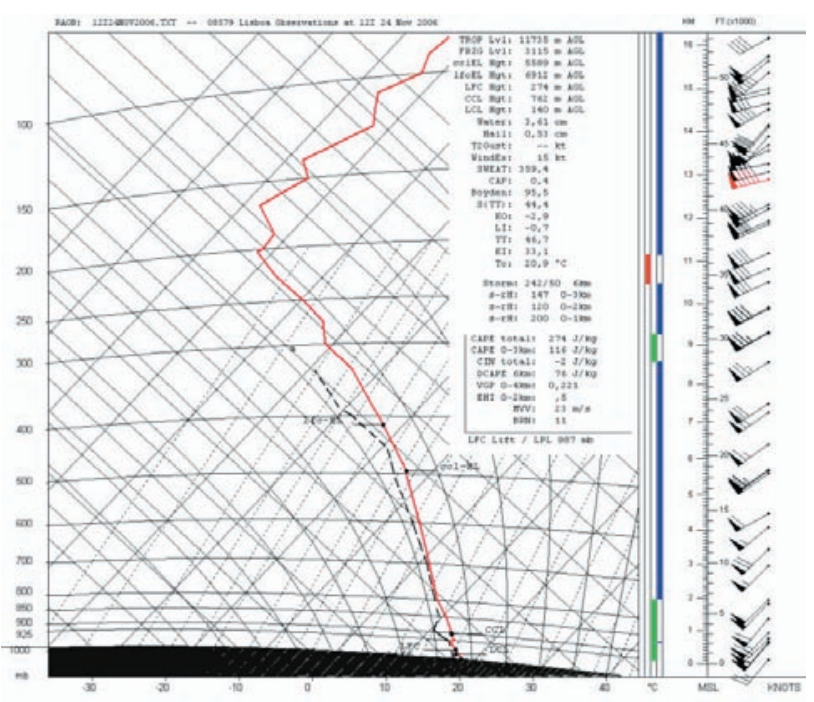

b)

Figure 12 - Windstorm on 24 November. a) Synoptic chart; b) sounding over Lisbon Airport (1200 UTC). Source: MetOffice (U.K.) and University of Wyoming, Dep. of Atmospheric Science. 
The most interesting feature in this profile is a low-level jet, with $29 \mathrm{~m} / \mathrm{s}$, blowing just 520 meters above the ground level.

This thermodynamic profile (Fig. 12b) shows a moderate highly instable atmospheric environment, favourable not just for the occurrence of surface gusts but also to thunderstorm activity and thick cloud formation, taking into account the availability of the moisture (precipitable water: $36.1 \mathrm{~mm}$ ) and convective energy to freely activate the lifting of the air from the lower levels. This event was responsible for the fall of 112 trees, boughs and branches.

\section{Conclusions and further research}

The fall of trees, boughs or branches occurs quite frequently in the city of Lisbon. To identify the causes of the falls of trees during windstorm events, a database was created and to date includes 946 occurrences of fallen trees (from 1990 to 2005), meteorological data (wind speed and direction), urban parameters (roughness length, H/W ratio, street orientation, street pollution levels, etc.), trees characteristics (diameter of the trunk, crown, height, age) and other conditions like fitossanitary state, soil, etc. Wind data and the occurrences were correlated with other data and the preliminary and general results were presented.

The main directions that cause tree falls were identified: Summer Nortada winds are responsible for $11 \%$ and the other directions for $5 \%$ of the falls (3\% from southwest and $2 \%$ from south and west). Most of the cases are related to the falls of boughs and branches. From autumn to spring, perturbed weather types from west, southwest and south (cyclonic circulations related to low pressure in connection with frontal systems or low-pressure centres located to the west or to the southwest of Portugal), are responsible for the most part of the occurrences (84\%), most of them affecting the whole tree, but also some boughs and branches. Infrequently, strong winds from downdrafts may also occur, such as those on 18 July 2006.

The majority of the falls (61\%) happened in the last five years, with the maximum of $19 \%$ in 2000 . Only $39 \%$ of the total of occurrences took place in the 1990s (with a maximum of $11 \%$ in 1997). It is possible that during this later period the trees had suffered higher stress due to urban factors, such as the increase in traffic and in the level of pollutants, which influence the fitossanitary conditions, in addition to the influence of age (since older trees are more vulnerable).

It was also found that the majority of falls happened when specific wind speed limits were surpassed, specifically above $7 \mathrm{~m} / \mathrm{s}$ for the time period that included the 6 hours prior to the occurrences.

For a successful implementation of an "alert plan" for the city during strong wind events, a few recommendations must be made: i) A common language must be defined among the RSBL technicians, potentially to be shared with researchers. This language should include a glossary of terms used in the description of the trees and the type of occurrences, besides the exact definition of the size of trees, boughs and branches and other important parameters;

ii) The precise location of the place of the occurrence is necessary to understand many of the factors that influence the fall of trees. A GPS device should be used for this purpose;

iii) A form, based on a checklist of the factors that may influence the falls, should be created and filled in by RSBL personnel with observations or measurements when the service is undertaken. The implementation of this method would allow for the creation of a reasonably complete database to be used in future analysis;

iv) The development of a training programme for the RSBL personnel, in order to clarify the methodology described and to ensure the correct application of the devices, as well as strengthening the working relations between researchers and RSBL personnel.

The methodology applied has proved suitable for this study, although some limitations were encountered. It is necessary to deepen our research and collect more data, with the purpose of understanding all the probable causes of tree falls in the city and assist in the development of contingency planning necessary to face these events.

\section{Acknowledgements}

The authors would like to thank to Prof. Maria João Alcoforado and Prof. Maria Eugénia Moreira for their review and discussion on this subject and for their advice concerning the methodology carried out in this research. We also have to thank to the Regimento de Sapadores Bombeiros de Lisboa, for their support and for the data supplied. Without their cooperation, this study wouldn't have been possible to develop.

This research was undertaken within the scope of the project "Climate and urban sustainability. Perception of comfort and climatic risks (URBKLIM)", funded by FCT (POCI/GEO/61148/2004).

\section{References:}

Alcoforado, M-J. (1987) - Brisas estivais do Tejo e do Oceano na região de Lisboa. Finisterra. XXII (43): 71-112.

Alcoforado, M-J. (1992) - O clima da região de Lisboa. Contrastes e ritmos térmicos. Memórias do Centro de Estudos Geográficos, vol. 15, CEG, Lisboa: 347 p.

Alcoforado, M-J.; Lopes, A. (2003) - Windfields and temperature patterns in Lisbon (Portugal) and their modification due to city growth. 5th International Conference on Urban Climate (ICUC5), Lodz, Poland: 383-386. 
Alcoforado, M-J.; Lopes, A.; Andrade, H.; Vasconcelos, J. (2005) - Orientações Climáticas para o Ordenamento em Lisboa, CEG/Geoecology, University of Lisbon, Report 4: 81p.

Birkmann, J. (2006) (editor) - Measuring vulnerability to hazards of natural origin. Towards disaster resilient societies. United Nations University Press, Tokyo.

Borges, J. (1971) - Structural Safety, Course 101, 2ºd., LNEC, Lisbon, 326 p.

Clergeau, P. (1996) - Urban biodiversity: is there such a thing? Le courrier du CNRS, $\mathrm{n}^{\circ}$ 82:102-104; and Cybergeo, (1996) - Les Bonnes Feuilles du PIRVILLES mis en ligne le 12 avril 1996, modifié le 31 mai 2007, (http://www.cybergeo. eu/index.html), Accessed on 11 June 2007.

DGRF - Ministry of Agriculture, Rural Development and Fishery / Forestry Resources (n.d.) - (http://www.dgrf.minagricultura.pt/v4/dgf/primeira.php) Accessed on 15 June 2000.

Dorland, C.; Tol, R.; Palutikof, J. (1999) - Vulnerability of The Netherlands and northwest Europe to storm damage under climate change. Climatic change 43: 513-535.

Doswell, C.A.; Brooks, H.E.; Maddox, R.A. (1996) - Flash flood forecasting: an ingredients-based methodology, Weather and Forecasting, 11:560-581.

Duryea, M. (1997) - Wind and Trees: Surveys of Tree Damage in Florida Panhandle after Hurricanes Erin and Opal; Institute of Food and Agricultural Sciences; Cooperative Extension Service; University of Florida: 2-7.

Fabião, A.M.D. (1996) - A agressividade do meio urbano e algumas medidas de mitigação do stress em árvores das cidades. Cirurgia das Árvores, Workshop, Lisbon.

Freer-Smith, P.H.; El-Khatib, A.; Taylor, G. (2004) Capture of Particulate Pollution by Trees: A Comparison of Species Typical of Semi-Arid Areas (Ficus Nitida and Eucalyptus Globulus) with European and North American Species, Water, Air, \& Soil Pollution, 155(1): 173-187.

Garcia-Martin, G.; Garcia-Valdecantos, J.L. (2001) - El arbolado urbano en las ciudades españolas. Actas del III Congreso Florestal Español: 467-474.

James, K. (2003) - Dynamic loading of trees. Journal of Arboriculture 29(3): 165-171.

Jim, C; Liu, H. (1997) - Storm damage on urban trees in Guangzhou, China. Landscape and Urban Planning 38: 45-59.

\section{Jornal de Notícias online edition (2000), 7 December.}

Kaňák, J.; Benko, M.; Simon, A.; Sokol, A. (2007) - Case study of the $9^{\text {th }}$ May 2003 windstorm in southwestern Slovakia, Atmospheric Research, 83: 162-175.

Krzyzanowski, M; Kuna-Dibbert, B.; Schneider, J. (ed.) (2005) - Health effects of transport-related air pollution, WHO.
Lopes, A. (2003) - Modificações no clima de Lisboa como consequência do crescimento urbano. Vento, ilha de calor de superfície e balanço energético, $\mathrm{PhD}$ thesis, University of Lisbon: 375 p.

Mattheck, C; Breloer, H. (1994) - The body language of trees. HMSO.London, UK.

McPherson, E.; Muchnick, J (2005) - Effects of street tree shade on asphalt concrete pavement performance, Journal of Arboriculture 31(6): 303-310.

Moreira, M.E. (1998) - Estudo Fitogeográfico do Jardim Braancamp Freire (Lisboa), Finisterra, XXXIII(66): 7-24.

Niklas, K. (2002) - Wind, size, and tree safety, Journal of Arboriculture, 28: 84-93.

Nilsson, K.; Randrup, T.B.; Wandall, B.M. (2000) - Trees in the urban environment. The forest handbook (Ed. Evan J), Blackwell Science, Oxford, Vol 1: 347-361.

OFDA/CRED International Disaster Database (n.d.) (http://www.em-dat.net/) Accessed in June 2007.

Peppler, R.; Lamb, P. (1989) - Tropospheric static stability indices and Central North America growing season rainfall, Monthly Weather Review, 117: 1156-1180.

Pokorny, J. (coord.) (2006) - Urban Tree Risk Management: A Community Guide to Program Design and Implementation. USDA Forest Service Northeastern Area State and Private Forestry, St. Paul, Minnesota.

Saebe, A.; Benedikz, T.; Randrup, T.B. (2003) - Selection of trees for urban forestry in the Nordic countries. Urban For. \& Urban Greening, 2: 101-114.

Santos, J.A.; Corte-Real, J.; Leite, S.M. (2005) - Winter regimes and their connection to the winter rainfall in Portugal, International Journal of Climatology, 25: 33-50.

Saraiva, J.G.; Marques da Silva, F.; Silva, F.G. (1997) - O vento, a cidade e o conforto. IV National Meeting on Comfort in Built Environments, Bahia, Brazil.

Shashua-Bar, L.; Hoffman, M. (2003) - Geometry and orientation aspects in passive cooling of canyon streets with trees, Energy and Buildings, 35: 61-68.

Soares, A.L.; Castel-Branco, C. (2007) - As árvores da cidade de Lisboa. Floresta e Sociedade. Uma história em comum. Ed. Público/FLAD:289-333.

World Health Organisation (WHO) (1999) - Health Costs Due to Road Traffic-Related Air Pollution, WHO, Copenhagen. 